\title{
Study of the Effect of Electroacupuncture Combination in Total Erythrocyte, Hemoglobin, and Hematocrit Values in Domestic Cat
}

\author{
Mudhita Zikkrullah Ritonga ${ }^{1,8,9}$, Muhammad Jalaluddin ${ }^{1}$, Wahyu Eka Sari ${ }^{2,5,8}$, Triva \\ Murtina Lubis ${ }^{3}$, Indah Novicia Putri ${ }^{4}$, Nurliana ${ }^{5}$, Arman Sayuti ${ }^{6}$, Teuku Zahrial \\ Helmi $^{7}$
}

\author{
${ }^{1}$ Laboratory of Anatomy, Faculty of Veterinary Medicine, Universitas Syiah Kuala, Banda Aceh, Indonesia \\ ${ }^{2}$ Laboratory of Research, Faculty of Veterinary Medicine, Universitas Syiah Kuala, Banda Aceh, Indonesia \\ ${ }^{3}$ Laboratory of Physiology, Faculty of Veterinary Medicine, Universitas Syiah Kuala, Banda Aceh, Indonesia \\ ${ }^{4}$ Study Program of Veterinary Education, Faculty of Veterinary Medicine, Universitas Syiah Kuala, Banda Aceh, \\ Indonesia \\ ${ }^{5}$ Laboratory of Veterinary Public Health, Faculty of Veterinary Medicine, Universitas Syiah Kuala, Banda Aceh, \\ Indonesia \\ ${ }^{6}$ Laboratory of Clinic, Faculty of Veterinary Medicine, Universitas Syiah Kuala, Banda Aceh, Indonesia \\ ${ }^{7}$ Laboratory of Biochemistry, Faculty of Veterinary Medicine, Universitas Syiah Kuala, Banda Aceh, Indonesia \\ ${ }^{8}$ Center for Tropical Veterinary Studies-One Health Collaboration Center, Universitas Syiah Kuala, Banda Aceh \\ ${ }^{9}$ Universitas Syiah Kuala Veterinary Teaching Hospital, Banda Aceh, Indonesia \\ *Corresponding author: ritongamz@unsyiah.ac.id
}

\begin{abstract}
Acupuncture is an alternative treatment originating from China. According to Traditional Chinese Medicine (TCM) the condition of blood insufficiency including blood deficiency and blood stagnation. The study aimed to determine the effect of electroacupuncture on erythrocyte number, haemoglobin level and hematocrit value in the domestic cat (Felis domesticus). This study used an experimental method with 6 domestic cats divided into 2 treated groups consisting of group A and group B. Group A received electroacupuncture stimulation of acupoint including BL-18 (Ganshu), SP-6 (Sanyinjiao), SI-3 (Houxi) and group B received electroacupuncture stimulation of acupoint including ST-36 (Housanli), BL-19 (Danshu), LIV-3 (Taichong). The duration of the electroacupuncture is 5 times with a period of 3 days. The blood was examined before (pre-test) and after (post-test) the electroacupuncture treatment using haematology analyzer. Data were analyzed using the Paired-Samples T-Test. The result of the study showed there are no significant differences of erythrocyte number, haemoglobin level and hematocrit level on group A and group B ( $p>0.05$ ). The conclusion is that electroacupuncture does not have a significant effect on total erythrocytes, hemoglobin levels and hematocrit values in domestic cats.
\end{abstract}

Keyword: Domestic cat, electroacupuncture, erythrocyte, haemoglobin, hematocrit

\section{INTRODUCTION}

The basic concept of blood disorders such as erythrocyte disorders consists of various causes of anaemia and polycythemia. The basis for providing anaemia treatment is to provide nutrients or insufficient ingredients to fulfil erythrocyte production (iron, vitamin B12), stop excessive erythrocyte discharge (in cases of bleeding), treat the cause of the disease if anaemia is secondary. Anaemia can also be relieved by giving blood transfusions to cats concerning ideal procedures. Meanwhile, the treatment of polycythemia is phlebotomy, bone marrow suppressants, surgery, and other medications $[1,2,3]$.

Blood profile is one of the laboratory tests to determine the physiological condition of the animal, 
including to diagnose anaemia. Parameters for measuring the state of erythrocytes are usually carried out by measuring the haemoglobin level in the blood in grams per deciliter $(\mathrm{g} / \mathrm{dL})$ and measuring the ratio of erythrocyte volume to blood volume (hematocrit) [4]. Other parameters for determining anaemia diagnosis are WBC, $\mathrm{MCV}, \mathrm{MCH}, \mathrm{MCHC}$, PLT, reticulocytes and blood smear [5].

Acupuncture is an alternative treatment for symptoms of diseases and illnesses and improves the physiological condition of the body. Acupuncture originates from China and has been known since 4000 years ago. Acupuncture is a method of treatment by inserting several needles into the patient's body. Qi or energy flows in its pathways, called meridians, and on these meridians acupuncture, needles can be inserted from points on the surface of the body (acupuncture points) to balance the Qi. Acupuncture techniques that are often used to treat patients in the veterinary field are needle acupuncture (manual), electroacupuncture, moxibustion, aqua-puncture, and gold implants [6].

According to Xie and Preast [7], acupuncture can treat various blood diseases such as anaemia, polycythemia, leukocytosis, and hypertension. In acupuncture, pathological conditions or disharmony in the blood include deficiency and stagnation. Blood deficiency is seen in the presence of blood insufficiency, due to haemorrhage or insufficient production of blood cells. In general, what is often seen is anaemia. Stagnation in the blood is caused by an obstruction in the bloodstream or accumulation of blood in the local area. Both of these conditions can be corrected with acupuncture [8]. This study aims to test the acupuncture points used for the effect of changes in erythrocyte total, haemoglobin levels and hematocrit values in domestic cat blood after being given electroacupuncture technique.

\section{MATERIALS AND METHODS}

The research was conducted at the Laboratory of Clinic and Shelter Campus B, Faculty of Veterinary Medicine, Universitas Syiah Kuala, Banda Aceh from December 2019 to January 2020. This research is an experimental study with a pre-post-test group design. This study included testing the activity of a combination of acupuncture acupoints on erythrocyte image, haemoglobin levels and hematocrit values in 6 female domestic cats with a weight range of 2-3 kg and aged 1-2 years in a healthy state which was divided into two treatment groups. Group A consisted of three domestic cats that received electroacupuncture therapy with a combination acupoint 1 point, namely BL-18, SP-6 and SI3 points. Group B consisted of three domestic cats who received electroacupuncture therapy with a combination of 2 acupoint points, namely ST-36, BL-19 and LIV-3 points. All cats were adapted to the research environment for three weeks in kennels.
Blood was drawn asepsis from the anterior cephalic antebrachial vein with a volume of $1 \mathrm{ml}$ and the blood was put into a vacuum tube containing the anticoagulant EDTA. Blood was drawn twice, namely before electroacupuncture and after electroacupuncture was done five times.

Electroacupuncture was given to the cat 5 times with an interval of 3 days of acupuncture. The duration of the experimental animal receiving acupuncture is 10 minutes per acupuncture. Electroacupuncture frequency used 1-2 $\mathrm{Hz}$ (low). The voltage used is 1.5 volts. The data analysis results were analyzed using the SPSS version 24 program. The acupuncture tool used was the JiaJian ${ }^{\circledR}$ electroacupuncture which consisted of a needle stimulator, stimulator cable, and $0.12 \times 13 \mathrm{~mm}$ HUANQUI acupuncture needles.

The blood samples taken were examined using a haematology analyzer (Mindray BC-2800, Shenzen Mindray Bio-Medical Electronics). The data obtained were analyzed using the Paired-Samples T Test method.

\section{RESULTS}

\subsection{Total Erythrocytes}

Based on the table 1, group A shows a significance value of $0.763(p>0.05)$, which means there is no significant difference in the increase in the total erythrocyte value of blood samples in cats given electroacupuncture with a combination of 1 acupoint point at pre-test and post-test. The mean total erythrocyte value at post-test was 8.26 , which was smaller than the mean total erythrocyte pre-test, which was 8.68 . This means that there is a decrease in the total value of erythrocytes after being given electroacupuncture treatment.

Group B showed a significance value of 0.067 ( $\mathrm{p}>$ $0.05)$, which means that there was no significant difference in the increase in the total erythrocyte value of blood samples in cats given electroacupuncture with a combination of 2 acupoint points at pre-test and post-test. The mean total erythrocyte value at post-test was 10.34 , which was greater than the mean total erythrocyte pre-test, which was 9.21, which means that there was an increase in the total erythrocyte value after being given electroacupuncture treatment.

\subsection{Haemoglobin Levels}

In the Table 1, the results show that group A shows a significance value of 0.759 ( $p>0.05)$, which means that there is no significant difference in the increase in haemoglobin levels of blood samples in cats given electroacupuncture with a combination of 1 acupoint point at pretest and posttest. The mean value of haemoglobin levels at the posttest was 12.400 , which was smaller than the mean pretest haemoglobin levels which were 13.167. 
This means that there is a decrease in haemoglobin levels after being given electroacupuncture treatment.

Table 1. Erythrocyte total, hemoglobin levels and hematocrit values table

\begin{tabular}{|c|c|c|c|c|c|c|c|c|c|}
\hline \multirow{3}{*}{ Group } & \multicolumn{3}{|c|}{ Total of erythrocyte } & \multicolumn{3}{|c|}{ Levels of hemoglobin } & \multicolumn{3}{|c|}{ Values of hematocrit } \\
\hline & \multicolumn{2}{|c|}{ Mean } & \multirow[b]{2}{*}{ Sig. } & \multicolumn{2}{|l|}{ Mean } & \multirow[b]{2}{*}{ Sig. } & \multicolumn{2}{|l|}{ Mean } & \multirow[b]{2}{*}{ Sig. } \\
\hline & $\begin{array}{l}\text { Pre- } \\
\text { test }\end{array}$ & $\begin{array}{l}\text { Post- } \\
\text { test }\end{array}$ & & $\begin{array}{l}\text { Pre- } \\
\text { Test }\end{array}$ & $\begin{array}{l}\text { Post- } \\
\text { Test }\end{array}$ & & $\begin{array}{l}\text { Pre- } \\
\text { Test }\end{array}$ & $\begin{array}{l}\text { Post- } \\
\text { Test }\end{array}$ & \\
\hline A & 8.68 & 8.26 & 0.763 & 13.16 & 12.40 & 0.759 & 41.30 & 37.20 & 0.547 \\
\hline B & 9.21 & 10.34 & 0.067 & 13.56 & 12.96 & 0.188 & 45.33 & 41.80 & 0.231 \\
\hline
\end{tabular}

In group $B$, it shows a significance value of 0.188 ( $p>$ 0.05 ), which means there is no significant difference in the increase in haemoglobin levels of blood samples in cats given electroacupuncture with combination acupoint 2 points at pretest and posttest. The mean value of haemoglobin levels at the posttest was 12.967, smaller than the mean pretest haemoglobin levels, which was 13.567. This means a decrease in haemoglobin levels after being given electroacupuncture treatment.

\subsection{Hematocrit Value}

According to the Table 1, group A shows a significance value of 0.547 ( $p>0.05$ ), which means that there is no significant difference in the increase in the hematocrit value of blood samples in cats given electroacupuncture with combination acupoint 1 point at pretest and posttest. The mean value of hematocrit at the time of the post-test was 37.200 smaller than the mean value of the pre-test hematocrit which was 41.300 . This shows that there is a decrease in the value of the hematocrit after being given electroacupuncture treatment.

In group B, it shows a significance value of 0.231 ( $\mathrm{p}>$ 0.05 ), which means that there is no significant difference in the increase in the hematocrit value of blood samples in cats given electroacupuncture with combination acupoint 2 points at pretest and posttest. The mean value of hematocrit at post-test was 41.800, which was smaller than the mean pretest, which was 45.333 . This means that there is a decrease in the value of the hematocrit after being given electro-acupuncture treatment.

\section{DISCUSSION}

The increase or decrease in total erythrocytes, haemoglobin levels and blood hematocrit values based on the table 1 are still normal. Normal values are caused by the cat being used in a healthy state and no symptoms of anaemia or other blood diseases. Dharmojono [9] states that in acupuncture, pain occurs when an imbalance between Yin and Yang occurs in the body which can be in the form of an excess (hyperfunction, too strong) or deficiency (hypofunction, too weak). Acupuncture stimulates the body's energy through needle pricks (Qi) so that the

body's energy is balanced and harmonious again. Because cats are used in a healthy condition, it means that the body's energy is balanced and the blood value is still within the normal range.

The target organ of the BL-18 (Gan Shu) point is the heart. The liver is a gland and an organ that has complex functions. The liver plays a role in the formation and excretion of bile, plays a role in the metabolism of macronutrients (carbohydrates, protein and fat), stores vitamins and minerals, metabolizes steroids, detoxifies and functions as a blood store and filtration [10]. Blood in the liver is nourished by nutritional substances in the spleen. The function of the spleen and stomach depends on the regulation of the free flow of Qi (energy) from the liver. With normal liver function, the movement of Qi flow is smooth and hematopoiesis can work. Consumption of kidney substances leads to blood deficiency and liver dysfunction, potentially causing loss of kidney essence/substance and can lead to symptoms of anaemia. Liver regulation therapy together with kidney tonification is an alternative to reduce symptoms of anaemia [11]. To get an increase in blood values it is recommended to use acupuncture points which can regulate the liver and tonify the spleen.

The target organ of the SP-6 (San Yin Jiao) point is the spleen. The spleen keeps blood in the blood vessels and prevents bleeding. Besides, the spleen functions in forming red blood cells during fetal life and in adults it is possible to still form it if the bone marrow function is damaged, damaged red blood cells are separated from the circulation, the spleen also produces lymphocytes, provides protection against disease and produces substances- antibody substances. The spleen is the basis of postnatal life, which controls the transport and transformation of nutritional substances from the stomach and is responsible for replenishing kidney starch. One approach to treating anaemia is to monetize the spleen [11]. Spleen tonification can relieve symptoms of anaemia because the spleen is located in the middle energizer, which means that the spleen is an organ that controls blood 
and the transformation of nutrients digested by the stomach.

The target organ from point ST-36 (Hou San Li) is the abdomen. The stabbing at this point can affect how the stomach works. The stomach and spleen are organs that are closely related to the starch found in the kidneys. One of the important nutrients for blood formation is formed from the activity of the stomach and spleen so that the stabbing at the ST-36 and SP-6 points can help facilitate the work of the stomach in digesting food that is good for blood and Qi formation [12].

Acupuncture points that can be used to treat anaemia are BL-18 (Gan Shu), ST-36 (Hou San Li) and SP-6 (San Yin Jiao). Anaemia is a chronic condition characterized by abnormal blood quantity due to bleeding, abnormal destruction of red blood cells and also the formation of insufficient haemoglobin and red blood cells as a result of insufficient food to form red blood cells. Anaemia occurs due to recurrent infections, is suffering from illness, lack of vit. E (important for the health of blood cells), insecticides that damage bone marrow, excessive blood loss and a very important factor is a lack of nutrients such as Fe, Vit. E, folic acid that enters the body. Symptoms of anaemia itself include dizziness when lacking oxygen, lethargy, fatigue, pallor, brittle nails, loss of appetite and pain in the stomach. Anaemia with a lack of nutrients for blood formation can be met from various food sources such as consuming green vegetables as a source of iron. Anaemia can be relieved by the use of acupuncture, an acupuncture point that is recommended to treat anaemia besides BL-18 (Gan Shu), ST-36 (Hou San Li), and SP-6 (San Yin Jao), namely RN / CV 12, ST-11, LU-7, SJ-6, DU / GV 14, BL-23, GB-25, BL-17 [13].

GB-39 acupuncture point (Xuan Zhong) can also be used as anaemia therapy. This point is a special point whose target organs go directly to the bone marrow. Stimulation from this point can stimulate hematopoiesis function. Based on the Sodipo study [14] the use of a combination of ST-36 (Hou San Li), SP-6 (San Yin Jao) and GB-39 (Xuan Zhong) points can increase haemoglobin levels and hematocrit values and improve physical, mental and patient well-being. with sickle cell anaemia.

Points ST-36 and SP-6 together with points DU-14 (Dazhui), BL-14 (Geshu), and LI-14 (Hegu) according to Hou et al. [15] can reduce bone marrow suppression and be able to enrich the blood, especially an increase in total leukocytes. This study did not show a significant effect on the increase in erythrocytes in patients with myelosuppression due to the use of chemotherapy drugs. The sample used was 191 patients with 52 patients in the acupuncture treatment group. Hou et al. [15] said that to get results in the form of an increase in total erythrocyte and haemoglobin, it would be better to increase the sample size and extend the frequency or repetition of acupuncture such as more than 120 days.

\section{CONCLUSION}

The use of electroacupuncture by using two combinations of acupoints did not show significant differences in total erythrocytes, haemoglobin levels and hematocrit values in domestic cat blood. Researchers suggest that further research should be carried out using cats affected by blood disorders.

\section{AUTHORS' CONTRIBUTIONS}

MZR, MJ conceptualized dan designed this research. The research was carried out by INP, WES, TML. N, TAS, TZH drafted, revised, and finalized the manuscript. All authors read and approved the final manuscript.

\section{ACKNOWLEDGMENTS}

We thank the Faculty of Veterinary Medicine, Universitas Syiah Kuala for the facility provided.

\section{REFERENCES}

[1] Gunanti, D. Endrawati, H.R. Supriadi, R. Siswandy, S. Agungpriyono, Identifikasi golongan darah dan kemungkinan hubungannya dengan warna rambut pada kucing domestik indonesia (Felis familiaris). Jurnal Kedokteran Hewan 7(1) (2013) 61-64.

[2] A. Tjokroprawiro, P.B. Setiawan, D. Santoso, G. Soegiarto, L.D. Rahmawati, Buku Ajar Ilmu Penyakit Dalam. Airlangga University Press, Surabaya, 2015.

[3] L. Waterbury, Buku Saku: Hematologi. Edisi 3. EGC, Penerbit Buku Kedokteran, Jakarta, 1998.

[4] R. Kiswari, Hematologi dan Transfusi. Edisi 4. Penerbit Erlangga, Jakarta, 2014.

[5] A.C. Guyton, J.E. Hall, Buku Ajar Fisiologi Kedokteran. Edisi 9. EGC, Penerbit Buku Kedokteran, Jakarta, 1997.

[6] A.L. Angeli, J.G.F. Joaquim, E.D.D. Gama, S.P.L. Luna, Outcome of 119 dogs and cats treated at theacupuncture unit of the faculty of veterinary medicineand animal science of the university of sãopaulo state, Botucatucity, Brazil. Braz. J. Vet. Res. Anim. Sci. 42(1) (2005) 68-74.

[7] H. Xie, V. Preast, Xie's Veterinary Acupuncture. Blackwell Publishing, Australia, 2007.

[8] A.M. Schoen, Veterinary Acupuncture. 2nd Edition. Mosby, US, 2001.

[9] Dharmojono, Menghayati Teori dan Praktek Akupunktur dan Moksibasi. Trubus Agriwidya, Jakarta, 2001. 
[10] R. Bijanti, M.G.A. Yuliani, R.S. Wahyuni, R.B. Utomo, Buku Ajar Patologi Klinik Veteriner. Airlangga University Press, Surabaya, 2010.

[11] N. Zhu, D. Wu, B. Ye, The progress of traditional Chinese medicinein the treatment of aplastic anemia. Journal of Translational Internal Medicine, 6(4) (2018) 159-164.

[12] K. Saputra, Akupuntur Dasar. Airlangga University Press, Surabaya, 2017.

[13] A.D. Dahlan, Buku Acupoints dan Dasar Acupunkture. Lembaga Kursus dan Pelatihan Ilalang, Bandung, 2015.

[14] J. Sodipo, Acupunture and Blood Studies in SickleCell Anemia. Amr. J. Chinese Med. 21(1) (1993) 8589.

[15] L. Hou, F. Gu, C. Zhou, Transcutaneous electrical acupoint stimulation (teas) ameliorates chemotherapy-induced bone marrow suppression in lung cancer patients. J. Thorac Dis. 9(3) (2017) 809817. 